\title{
Swimming with sharks, ecological feminism and posthuman language politics.
}

\begin{abstract}
In this paper we ask how critical language studies can be rethought to promote a better understanding of the place of humans in the more-than-human world. We discuss the growing body of work that relates concern with the environment with other forms of political activism, particularly ecological feminism.

Broadening this discussion to focus on the place of language and pedagogy in the myth of human exceptionalism, we ask what this means for human engagement with the more-than-human world. The critical posthuman language project we propose overturns the assumptions of human centrality that have underpinned much educational thought and practice, questions the ways in which we define the human and non-human, and opens up new forms of engagement with the material, corporeal and affective world.
\end{abstract}

\section{Swimming with sharks}

06:00 Shelly Beach, NSW coast: Late summer and the air and water are warm. I slip into the salty ocean in my cossie and a pair of plastic goggles, hoping to swim with sharks. My feet leave the sandy bottom and I look straight down as I glide over waving seaweeds and schools of tiny fish. When I meet a massive school of yellowtail I reach out in the vain attempt to touch their shiny bodies with mine. I know I never will, they dart away so quickly. I keep swimming steadily, breathing from side to side, heading towards the area that my swim friends call 'shark alley'. Then I see one, two, a dozen or more: dusky whaler sharks. Their muscular bodies move through the water so effortlessly, propelled by a graceful tail wave. We have so many with us this season, I'm not sure why. We're grateful for their presence. Later today, a few beaches to the north of where I swim, the bloody bodies of two juvenile dusky whaler sharks are found abandoned on the beach. They each measure only a metre in length, they have hooks in their mouths and their flesh is punctured by stab wounds. Although they've been 
caught by fishers with hooks and lines, they've not been treasured as food for humans. A report of the incident in our local newspaper (Cross 2016) says the sharks were probably killed for a 'selfie'. How very twenty-first century.

10:00 North Solitary Island, NSW coast: The boat is moored in what is known as Anemone Bay on the northeast side of the small island. We've finished our first dive of the morning, circling the spectacular garden of anemone and clown fish that fill the rocky cove. As we drink soup and discuss where to do our second dive, news comes of a large gathering of Grey Nurse sharks round the point. A quick vote and we agree to change locations and dive with the sharks. Grey Nurse sharks are beautiful creatures: they have the classic 'shark look' (unlike, for example, the funky wobbegong sharks in Sydney) and grow to two to three metres in length. So the second dive we drop down amid a school of magnificent sharks and watch as they swim around us (less interested in us than we are in them). Perhaps, my partner tells me later, I was pushing things a bit far when I settled down into a sandy gully between the rocks to watch a dozen of these graceful creatures circling above my head, but neither they nor I was very bothered by this. So yes, we went looking for the sharks (they weren't looking for us), and when at other times we don't see sharks (in five days of a Saving Philippines Reefs expedition in Coron in April 2016 we saw none) we are worried: either the sharks have been killed or their food sources - which we share with them - have disappeared.

\section{Critical embodied practice}

We have started this paper with accounts of 'swimming with sharks' to ground our work in an everyday practice. To suggest that we both regularly swim with sharks (Applebyuthor 1 as a daily ocean swimmer off the northern beaches of Sydney; Pennycook as a regular scuba diver) may seem an alarming statement

But it is to draw attention to the alarm sharks cause and the discourses that produce this alarm that is precisely part of the point we wish to make. Sharks 
come in many shapes and sizes (see images 1-3) and are far more threatened by humans than the other way round (Grey Nurse sharks are a protected species). To be sure, there are occasional shark attacks (not always an accurate term since they might be better described as shark taste tests), but it is the ways these are taken up (leading to shark culling, shark nets, and general shark alarmism) that is part of the problematic human relationship to many of our fellow animals.

Australia is a context of strong arguments about sharks and these are exemplified in a range of texts. The language used in media reports of shark encounters seems designed to promote public alarm by demonising sharks, and yet public responses to these encounters are decidedly mixed. Thus, a recent article (Dapin, 2016) suggests that victims of shark attacks have to suffer not only the trauma of the attack but also subsequent attacks by those who feel little sympathy: They had it coming. This article focuses on the 'Bite Club', an organization to assist those who've suffered shark bites (it has 250 members of whom 50 have suffered bites). The 'Bite Club' name inevitably evokes the iconic novel and movie 'Fight Club', which explored through its story of physical bravado and violence the supposed crisis in masculinity at the dawn of the new millennium. The dubious argument in the media article - that those bitten by sharks suffer doubly - is that as an over-focus on particular incidents with sharks is met (online mainly) by conservationist comments criticising the surfers for entering the territory of the sharks, surfing at the wrong time of day and so on: "What was the surfer doing in the water? It's the shark's ocean anyway;" "Oh, how surprising! A shark in the ocean;" "This guy's a fool. He shouldn't be surfing. It's his own fault he got attacked."

There are several discourses that need to be disentangled in all this. The first is that Australia and its beaches - produced through an interplay of place-based language, people, and marine animals - are highly dangerous. Australians play this up, particularly to tourists, emphasising the range of sharks, spiders, snakes the country offers. Fatal shark attacks are not really a major concern anywhere in the world (at least for humans - for many fish it's a much more serious issue, and if you've ever seen reef sharks feeding on a school of jacks, you know that 
being a fish isn't always fun). A second discourse downplays the risk posed by sharks, pointing to all the other things that are more dangerous, including cows, vending machines, falling coconuts, champagne corks and so on. The figures here of course are rather unreliable and the statistics problematic since relative numbers of people engaging in certain activities are not calculated.

In fact, statistical records show that sharks are unlikely to pose a danger for humans. In 2015 there were 31 recorded 'shark attacks' in Australia: 21 were classified as 'unprovoked' that is to say the swimmer, surfer or diver did not do anything to provoke the attack before the incident. There were two fatalities in 2015 - a Japanese surfer and a Tasmanian scallop diver. 269 more people in Australia died from drowning than from shark bites in 2015. In the previous 50 years there has been just under one unprovoked shark attack fatality per year in Australia (47). There have been 234 fatalities (183 unprovoked, 51 provoked ${ }^{2}$ ) since Europeans invaded Australia and started keeping records in 1791 (Taronga Zoo, 2016). The number of attacks has risen, however, a result it seems of greater number of surfers spending a longer time in the ocean in winter, and various climate and feeding changes leading to more bait fish closer to the shore and larger populations of migrating whales attracting sharks to certain waters.

The second discourse is a masculinist one and has to do with fighting off sharks. Indeed for all its initial focus on the backlash from conservationists, media articles continue to dwell on stories of the attack, the survival, and best of all, the punch to the nose, the finger in the eye. Fighting off the shark becomes a mark of masculine pride, enhanced greatly when an Australian world champion surfer

\footnotetext{
2 An 'unprovoked' encounter between a human and a shark is defined as an incident where a shark is in its natural habitat and has made a determined attempt to bite a human where that person is not engaged in provocative activities.
}

A 'provoked' incident relates to circumstances where the person attracts or initiates physical contact with a shark (accidently or on purpose) or was fishing for, spearing, stabbing, feeding, netting or handling a shark or where the shark was attracted to the victim by activities such as fishing, spearfishing, commercial diving activities (actively collecting abalone, pearl shells, or other marine animals) and cleaning of captured fish. 
was filmed fighting off a shark while surfing in South Africa. Building up the shark menace is part of Australian nationalism and masculine aggression. In response to a number of shark encounters on the north coast of NSW, another media article (Robson, 2015) pits the heroic male surfers against the marine ecologists. On one side, a local ecologist insists that "There has not been a spike in shark attacks" and argues that "these are not attacks, they're encounters. Sharks don't eat humans, they spit us out". On the other side, we are presented with the "veteran Evans Head surfer" and ex-boxer who escaped from "a great white shark that tried to eat his left leg ... by punching the shark during the frenzied mauling, but he almost died through blood loss and was left in no doubt about the shark's intention".

Yet this kind of analysis of shark discourse takes us so far, but then leaves us short. In the rest of this paper we argue that a new critical approach to language studies needs to attend to several new ways of thinking and writing (hence in part the opening descriptions of encounters with sharks). As Thurlow (2016) makes very clear, the tools of critical discourse studies, for example, have many gaps, contradictions and weaknesses. In his project of 'queering' discourse studies, he suggests that queer "disrupts and challenges the received ' here-andnow' wisdoms of academic theory and promotes a more self-reflexive, openly subjective role for the scholar" while remaining "committed to the future and to corporeal realities" ( $p$ 490). Alongside this disruption of the academic gaze, Thurlow also advocates "more performativity in our writing, allowing for alternative ways of knowing, and of showing what we know" (p491).

So there is another important point we wish to make about swimming with sharks. For some, these accounts might seem like stuff we do outside our own domains of critical practice: swimming before work; diving during breaks. These divisions are also something we want to question, however, since they divide academic practice and bodily engagement, nature work and culture work, intellectual activity and pleasure. A significant part of the argument we wish to make in this paper is that swimming with sharks is part of, not prior to or alongside, our critical practice. This is to take up an understanding of the subject 
as embodied, embedded and materialist, and to understand critical work less in terms of the demystification projects of ideology critique (which reduce political agency to human agency) and instead in terms of a politics that reorients humans towards their ethical interdependence with the material world (Bennett, 2010a).

\section{Intersections of old and new materialisms}

It has long been a truism of critical theory and practice that we need to understand how different forms of discrimination, inequality and difference intersect. Any contemporary critical language project needs to engage with current social, economic and political concerns such as neoliberal ideologies and practices and their relationship to the global spread of English (Chun, 2015; Holborrow, 2015), causes of and responses to forced migration (Lorente, in press; Sabaté I Dilmau, 2014; Standing, 2014), the rise of the populist new right and its pernicious discourses (Wodak, 2015), the racial construction of native speakers (Kubota and Lin, 2009; Kubota, 2014; Motha, 2014), or the ways that classrooms, teaching styles, hiring practices and language marketing embrace racial, heteronormative and masculinist stances (Applebyuthor 1, 2014).

All these are obvious starting points for any critical project in the field. Widely accepted too is an understanding of the need to embrace the ways these intersect. Arguing against the notion of a "universal basis for feminism, one which must be found in an identity assumed to exist cross-culturally," Butler (1990, p3) suggested long ago that gender is "not always constituted coherently or consistently in different historical contexts" since it "intersects with racial, class, ethnic, sexual and regional modalities of discursively constituted identities." According to Block and Corona (2016) the current consensus is that "identity is multilayered and complex" and "different dimensions of identity cannot be dealt with in isolation from one another" (p. 509) so that to ignore the intersections between gender, race, class, and sexuality is to produce a narrow and inadequate analysis. 
Yet the argument we want to pursue in this paper suggests not only that we need to understand the intersections of these old materialisms but that we also need to understand the relation to new understandings of materialism. This is to take more seriously the idea that "technological and natural materialities" might themselves be understood as "actors alongside and within us" as "vitalities, trajectories, and powers irreducible to the meanings, intentions, or symbolic values humans invest in them" (Bennett, 2010b, p. 47). PennycookThis return to materialism involves a reconsideration of what matter means: For Barad (2013: 17) matter "is not mere stuff. It is not an inanimate givenness." This is a political project not in the Hegelian-Marxist line of thinking, where social class and political economy define material realities, and the critical response is one aimed at exposing the obfuscatory work of ideology, but rather a project of queering discourse studies (Thurlow, 2016) as part of an alternative politics of humans and the world. Why, we might ask, do particular accounts of the material (socioeconomic infrastructure) count as more material than other accounts of the body, sexuality and performativity?

It is not, as Bennett (2010a) reminds us, that we need to reject the old materialisms (class and economy still matter) but rather that a "dogged resistance to anthropocentrism" opens up an alternative way of thinking about "vital materialism" alongside "historical materialism" (p.xvi). We need therefore to engage with new intersections between the politics of old and alternative discourses (ecofeminist amongst others), and a new set of possibilities opened up by posthumanist framings of the relations between humans and their others (Author 2, 2016). How can critical language studies be deployed to promote a better understanding of the place of humans in the more-than-human world? The question of what it means to be human (defined always in relation to those deemed non-human) needs to be taken as seriously as questions of class and race (the two questions are in fact deeply related). Put another way we are concerned about the "ontological precariousness" (Fuller, 2011: 72) of both humans and sharks. 
As Adams and Gruen (2014) explain, an ecofeminist position addresses the various ways that sexism, heteronormativity, racism, colonialism and ableism are interconnected with speciesism - prejudicial relations with other species. The starting point from this perspective is the realization that the othering of women is aligned with the othering of non-human animals, and needs to be addressed from a feminist, environmentalist and posthumanist perspective. This is part of a growing argument for the need from a critical perspective to engage with the 'more-than-human world'. Although the term posthumanism embraces a wide range of positions including transhumanism and the convergence of humans and technology, one important aspect of our project is in the ways in which language shapes our engagement with, and understanding of, life in relation to animals and non-animal others.

These challenges are also a product of the very real material changes brought about by climate change and the Anthropocene, where humans are now seen as "a force of nature in the geological sense" (Chakrabarty 2009: 209). Latour (2015: 146) notes that the Anthropocene may help us finally reject the "separation between Nature and Human that has paralysed science and politics since the dawn of modernism." The Anthropocene potentially marks the end of the nature/culture divide that has been a central part of the thinking of Western modernity (inhuman nature, human culture). The assumptions of modernity that nature is external, a resource to be exploited, that humans are separate, selfgoverning, on an upward spiral of self-improvement to escape the limits of nature - are coming under scrutiny. If 'ecological' concerns seem potentially 'soft' critical ideas compared to class, gender and race, we want to argue by contrast that they are deeply bound up with each other, and there is nothing 'soft' about considering what it means to be 'living in the end times' (Žižek, 2010).

Critical studies of humans in relation to a posthumanist world draw on a wide range of critical social theories, posing questions as to how understandings introduced through feminism and feminist research, or research inspired by Marxist or postcolonial frameworks, contribute to language studies for a more- 
than-human world (Haraway, 2008). How, for example, do old staples of critical praxis - consciousness-raising, allowing/promoting the 'voice' of 'others' (and what are the limits in relation to 'voiceless' others?), focusing on the discursive and material, taking action, and accepting loss of hu/man privilege - look from this different perspective? What are the limits of language studies - and (human-designed) research approaches more broadly - in understanding nonhuman-animal others? Are conventional means of social/textual representation sufficient for a meaningful engagement in the more-than-human world? Humananimal lives are intimately entangled, but what oppressions and invisibilities and language practices enable and sustain certain normative entanglements, such as 'carnism' (the commodification, exploitation and consumption of non-human animals)? How can language studies be deployed to promote alternative types of entanglement (Cook, 2015)? What potential do 'critical animal studies' offer to mobilise 'affect', in addition to 'reason', as a mode of engagement?

In the next section we discuss the growing body of work that relates concern with the environment with other forms of political activism, particularly ecological feminism. Next, we broaden this discussion to focus on the place of language and pedagogy in the myth of human exceptionalism: what does this mean for human engagement with the more-than-human world (boundaries, superiority, distancing, oppression, and so on)? Finally, moving beyond human exceptionalism, we ask what sort of questions might motivate critical posthumanist language studies? What inspirations can we draw from social justice movements already adopted in CLS - feminist analyses of gender, antiracist and postcolonial studies (Motha, 2014), Marxist analyses of class (Block, 2014) - for an educational and linguistic engagement with the posthuman (Pedersen, 2010)? How can our research into and understanding of language be used in critical pedagogy to involve students in the more-than-human world?

\section{Critical ecological feminism}

Within a broader feminist framework that emphasises situatedness and materiality (Braidotti 2013), concern for the relationship between humans and 
the environment has long been a focus for feminist activism and philosophy. As Mies and Shiva (2014) point out, ecofeminism is deeply intersectional in that it spells out the historical links between environmental degradation, patriarchy, neoliberal capital, corporate science, neocolonialism, and the myth of progress through limitless growth. In similar ways, Plumwood (1993, p. 1), proposing the development of a 'critical ecological feminism' observed that 'the oppressions of gender, race, class and nature' have come together, and that an adequate account of the 'domination of nature' must necessarily draw on 'accounts of other forms of oppression'. Building on feminist critiques of dualism in western philosophy, Plumwood sees the relationship between 'reason' and 'nature' as a foundational binary, with reason 'constructed as the privileged domain of the master' (formed in the context of race, class, species, and gender domination) and, on the other side, nature conceived as a domain of subordinate embodied others, both human and non-human, a field of 'multiple exclusions and control', a resource 'empty of its own purposes or meanings' (p. 4). In an era of environmental crisis, reconfirming the agency and intentionality of nature is 'no longer simply a matter of justice, but now also a matter of survival' (p. 6).

Nevertheless, the traditional associations between 'woman' and 'nature' in Western culture have made 'nature' a difficult domain for feminists who remain ever wary of biological essentialism. A rejection of biological essentialism has been a motivating force in poststructuralist feminisms which have tended to elide material bodies in favour of discursive accounts that distance gender (as a cultural, performative construct) from the flesh of material bodies (Alaimo \& Hekman 2008). More recently, however, material and environmental feminisms have sought to address this impasse by developing a different engagement between culture and nature, one that builds on and enriches understandings that emerged from poststructuralism and adds to these an ethics of respect and care for the more-than-human world. For feminist philosophers, such engagements highlight not only the interaction between (human) culture and biological nature, but also encompass entanglements amongst these and an array of technological artefacts (including objects, genetic manipulation, virtual realities, human-machine interfaces, and so on) memorably presented in the form of the 
cyborg (Haraway, 1983) or, in this century, the selfie. A feminist posthumanism, then, challenges the category of human as privileged and reminds us that all bodies - human, nonhuman, and technological - 'exist in entanglements' (Springgay, 2015, p. 81).

An important strand in critical, posthuman ecological feminism builds on earlier feminist work from scholars such as Plumwood (1993), Gruen (1993), Adams and Donovan (1995) and focuses on the relationship between human and nonhuman animals. This strand of feminist scholarship is concerned with the ways in which 'sexism and speciesism mutually inform one another' (Gruen \& Weil, 2010, p. 127) and entails a disruption of species boundaries and of the concomitant hierarchies that posit human superiority and exclusion from (and domination of) the natural world. As Gruen and Weil (2010) explain, speciesism is akin to sexism and racism in that each involves the "prejudicial view that there is an ontologically distinct marker, in this case species membership, that adds value to those who belong to the human species and justifies domination of those who don't' (p. 127). Feminist animal studies challenges the forces that contribute to Othering and domination by fostering new epistemological paradigms that recognise agency in the more-than-human world. Drawing also on material feminism, the focus here has been on the intra-action rather than distinction between beings (Barad 2003) and on the necessary and transformative entanglements of human and non-human animals (Haraway 2003, 2008). In the wake of these developments in feminist theory, the field of critical human-animal studies, with its emphasis on post-anthropocentric 'species egalitarianism' has emerged in recent years as one of the most productive areas of new posthumanist scholarship (Braidotti, 2013, p. 146).

\section{Posthuman language and pedagogy}

We are arguing for a rethinking of the relationship to all those Others that suffered in the construction of humanity: gods, machines, objects, things, animals, monsters, women, slaves, and so on (Haraway, 2008; Latour; 2004). Central to this is also the question of what it means to be human. The posthuman condition, suggests Braidotti (2013: 1-2) "introduces a qualitative shift in our 
thinking about what exactly is the basic unit of common reference for our species, our polity and our relationship to the other inhabitants of this planet." Ferrando (2013: 26) elaborates that posthumanism is an umbrella term responding to the need to rethink what it means to be human in light of both "onto-epistemological as well as scientific and bio-technological developments of the twentieth and twenty-first centuries." It can be seen as "the reordering of social identity as a reciprocal exchange between thinking bodies, machines and environments" (Amin, 2015: 245)

The pedagogical and applied linguistic implications of all this are several. In terms of education and research in applied linguistics, posthumanism provides 'a tool to transcend traditional disciplinary boundaries between natural sciences and social/humanist sciences' and to study the entanglement between human and nonhuman agencies (Pedersen, 2010, p. 246). With its shift in the unit of analysis - from hu/man to nature-culture assemblages and entanglements posthumanism offers a means of broadening our perspective to encompass a range of actants, their histories, trajectories, effects, and the consequences of their interactions for environmental sustainability and ecosystem survival. Because of its breadth, a posthumanist perspective that encompasses human/animal/machine/thing relations has the potential to 'reconfigure education' in its entirety by overturning an understanding of human centrality that 'has undergirded virtually all educational thought in the West' (Snaza \& Weaver, 2014, p. 1).

From this broader perspective, linguistic and applied linguistic scholars have deployed traditional tools to examine the ways in which human-animal relationships are represented in language. For example, Stibbe $(2014,2015)$ has written extensively on the topic of 'ecolinguistics', a term he uses to extend critical discourse studies beyond a focus on human power relations to consider 'practical issues of pressing importance in the twenty-first century such as environmental justice, water scarcity, energy security, and in general, the gradual destruction of the ecological systems that support life' (2014, p. 584). Ecolinguistics is borne out of a perception that 'mainstream linguistics has forgotten, or overlooked, the embedding of humans in the larger systems that 
support life' (Stibbe, 2014, p. 585), and is concerned not only to critique destructive discourses but also to search for alternative discourses that reflect new ways of thinking and talking about the world. Of particular interest to Stibbe (2012) have been the ways language contributes to the oppression and exploitation of nonhuman animals. The "role of language in the conceptualisation of animals" (Cook, 2015, p. 588) and in shaping the relationship between human and nonhuman animals has also been of interest in the work of Moore (2014), and has featured in Appleby'sAuthor 1's work on human-shark relationships (2016).

Questioning the role of language in scribing an opposition between humans and animals is part of an inquiry of what it means to be human, the ways in which we define the human and non-human, animals and non-human animals. What in part makes humans human is our connection to animals. A "defining trait" of what it means to be human has been " a connection with animals" going back over millions of years (Shipman, 2011, p.13). Yet human exceptionalism, emphasizing a distinction between humans and animals, as Cook (2015: 591) suggests, is "the default view in the contemporary United Kingdom, if not the world" as evidenced in many practices incompatible with animal rights. As Haraway (1991) argues, animal rights are "not irrational denials of human uniqueness; they are a clear-sighted recognition of connection across the discredited breach of nature and culture" (p.152). The division between animals and humans therefore ties to the broader divisions between nature and society/ culture, between the natural sciences and the humanities/ social sciences, which as Urry (2011: 7) points out "mostly operate on the clear separation between nature and society." In more recent work, Haraway (2008: 4) explores the relationship between species, arguing that "species of all kinds, living and not, are consequent on a subject- and object-shaping dance of encounters." Our interest, then, is not only in animal rights (a reconsideration of the killing of sharks, for example, because they're scary), or the discursive representation of animals (Cook, 2015), but a broader set of questions about human exceptionalism. 
Moving beyond human-animal entanglement, the relationship between humans, affect, and lively objects is central to Thurlow's (2016) 'post-class' critical discourse analysis. Thurlow's queering of critical discourse analysis also raises the prospect of new ways of writing to engage with the material, corporeal and affective world. New ways of writing, with an adequate language for postanthropocentrism, 'means that the resources of the imagination, as well as the tools of critical intelligence, need to be enlisted for the task' (Braidotti, 2013, p. 82). One such 'new genre of writing' is the creation of multispecies ethnographies which foregrounds the 'biographical and political lives' of 'creatures previously appearing on the margins of anthropology', such as animals, plants, fungi and microbes (Kirksey \& Helmreich, 2010). Drawing inspiration from Haraway's explorations of multispecies nature-culture engagements, multispecies ethnographtraverse traditional disciplinary fields of arts, science, literature, and language to represent the posthuman perspective in new ways

The posthuman project suggests a shift in the understanding of the subject, which is by no means the same as the postmodern (anti-foundationalist) or poststructuralist (discursive) subject, since it is "materialist and vitalist, embodied and embedded" (Braidotti, 2013: 188). This points to the need in critical language studies not only to take up new forms of materialism, embodiment, and the significance of place, but also to challenge the notion of representationalism that underpins much of traditional critical discourse analysis. The belief that we have better access to representations of things than the things themselves, Barad (2003: 806-7) suggests, is "a contingent fact of history and not a logical necessity; that is, it is simply a Cartesian habit of mind."

Questioning the assumption of human exceptionalism suggests, in line with other erosions of the borders between humans and non-humans, that language will need to be seen as involving a far broader set of semiotic resources, sites and 
interactions than is posited by a humanist vision of language. In order to align itself with current changes to the planet, humanity, theory and politics, a useful way forward may be to take seriously posthumanist thinking that "eschews both humanist and structuralist accounts of the subject that position the human as either pure cause or pure effect, and the body as the natural and fixed dividing line between interiority and exteriority. Posthumanism doesn't presume the separateness of any-'thing,' let alone the alleged spatial, ontological, and epistemological distinction that sets humans apart" (Barad, 2007: 136).

We might therefore start think about critical language studies beyond language. Linguistics and applied linguistics have been significant disciplines in the maintenance of the idea of human exceptionalism, a core tenet being that language is what separates us from the animals. Human language is considered unique and unrelated to animal communication (Evans, 2014), a necessary proposition for the belief that language is a system separate from broader modes of communication, a system that sprang into being in an evolutionary jump rather than a more commonplace development from animal modes of communication. Many linguists, and by extension much of applied linguistics, had to therefore posit a distinction between humans and non-humans, between language and non-language. Yet it is now clear that "the distinctive qualities of human language" do not suggest "a sharp divide between human language and non-human communicative systems" (Evans, 2014, p 258).

An alternative way forward may mean taking up in a material sense, and educating our students about, an actual, corporeal engagement with the world of nature-cultures, promoting a curiosity about the multiple ways in which humans are always inevitably entangled with, and shaped by, the lives of organic and inorganic others. From the perspective we are developing here, a critical posthuman language project overturns the assumptions of human centrality that have underpinned much educational thought and practice, questions the ways in which we define the human and non-human, and opens up new forms of engagement with the material, corporeal and affective world. A posthumanist 
perspective requires us to rethink these claims to both human and linguistic exceptionalism, and to appreciate the beauty of swimming with sharks.

\section{Conclusion: Critical posthumanist applied ecolinguistics}

Pennycookin pressTo ditch language and humanism from a critical linguistic project might seem like utter folly. As Bucholtz and Hall (2016, p 187) suggest, “just as critical theory's discursive turn once validated our object of study, the posthumanist turn may seem to threaten to undermine it". And yet, as they go on to suggest, many areas of socioculural linguistics have already been working in ways that contribute to a posthumanist understanding of people and things, in a way that "dissolves the discourse-materiality dichotomy by analyzing semiosis as a process that emerges in the mutually constitutive actions that take place between human bodies and the other entities with which they interact" (2016, 187). The aim is not to get rid of humans and language but to reorganize them, put them where they belong, not always so much at centre stage but rather in the periphery, as apart of a larger understanding of semiotics and politics.

Our relationship with sharks is not merely about humans and dangerous fish but a much more complex set of relations that are part of the construction of humans, language, masculinity, culture, nature, materiality. This is not, therefore, an argument only for greater ecological care, for critical analysis of environmental discourse, or for more attention to non-human animals in language studies. This is part of an attempt, both analytic and pedagogical, to rethink human-animal relations. At the same time, it is also part of an attempt to queer critical studies, to question the position of critical analysts in the world around them, to ask not only what role language plays in this but what role it doesn't play. And it is also part of a project to find alternative modes of engagement, ways of dealing with the world that encompass bodily and affective modes. 
Chakrabarty (2000) argues for the need to provincialize Europe, his point being that he cannot and does not wish to reject all that is European - Marxist analysis had been crucial for his own work on class and history in India - but that it is time to put European thought where it belongs, more on the periphery. Following this line of thinking, Motha (2014) argues for an understanding of "provincialized English" where "no teacher would teach English without an explicit consciousness of the hierarchies that the language is positioned within and of how the teaching of English shapes racial categories" (p.129). English and English teaching would not be rejected but would be understood in their specific localities. In his queering of discourse studies, Thurlow takes the provincializing project one step further, arguing that we need "not to deny language but to provincialize it: to recognize its limits, to acknowledge its constructedness, and to open ourselves up to a world of communicating and knowing beyond - or beside/s - words. And this will likely require a more committed decentering of language than even multimodal analysts have been able to manage" (Thurlow, 2016, p. 503).

Our own proposal builds on this line of thinking and seeks to provincialize both language and humanity in a renewed approach to critical applied linguistics. Posthumanist thought suggests a stronger and more dynamic role for objects and space, focusing on "how the composite ecology of human and nonhuman interactions in public space works on sociality and political orientation" (Amin, 2015: 239). From this point of view, there is a strong focus on both practices those repeated social and material acts that have gained sufficient stability over time to reproduce themselves - and on "the vast spillage of things" which are given equal weight to other actors and become "part of hybrid assemblages: concretions, settings and flows" (Thrift, 2007: 9). The move toward "performative alternatives to representationalism", Barad (2007: 135) argues, "shifts the focus from questions of correspondence between descriptions and reality (e.g., do they mirror nature or culture?) to matters of practices, doings and actions." This takes us into a mode of critical engagement that is still feminist, anti-racist and anti-homophobic, is still concerned with discrimination and inequality, but does not at the same time privilege humans and language in 
the critical project. It aims instead to understand the entanglements and assemblages of humans, objects, other animals, sharks, oceans and daily swims. 


\section{References}

Adams, C.J. \& Donovan, J. (Eds). (1995). Animals and women: Feminist theoretical explorations. Durham and London: Duke University Press.

Adams, C. \& Gruen, L. (2014). Introduction. In C. Adams and L. Gruen (Eds.), Ecofeminism: Feminist intersections with other animals and the earth (pp. 136). London: Bloomsbury.

Alaimo, S. \& Hekman, S. (Eds). (2008). Material feminisms. Bloomington: Indiana University Press.

Amin, A. (2015). Animated space. Public culture, 27(2), 239-258.

Appleby, R. (2014). Men and masculinities in global English language teaching. London: Palgrave.

Appleby, R. (2016, May 21). Gender, language and sharks. Paper presented at the International Gender and Language Conference, Hong Kong.

Barad, K. (2003). Posthumanist performativity: Toward an understanding of how matter comes to matter. Signs: Journal of Women in Culture and Society, 28(3) 801-831.

Barad, K. (2007). Meeting the universe halfway: quantum physics and the entanglement of matter and meaning. Durham: Duke University Press

Bennett, J. (2010a). Vibrant matter: A political ecology of things. Durham: Duke University Press.

Bennett, J (2010b) A vitalist stopover on the way to a new materialism. In D Coole and S Frost (Eds) New materialisms: Ontology, agency and politics. Durham, NC: Duke University Press (pp 47-69) 
Block, D. (2014). Social class in applied linguistics. London: Routledge.

Block, D. \& Corona V. (2016). Intersectionality in language and identity research. In S. Preece (Ed.), The Routledge handbook of language and identity (pp. 505-522). London: Routledge,.

Braidotti, R. (2013). The posthuman. Cambridge: Polity.

Bucholz, M and K Hall (2016) Embodied sociolinguistics. In N. Coupland (Ed.), Sociolinguistics: Theoretical Debates. Cambridge: Cambridge University Press (pp 173-197).

Butler, J. (1990). Gender Trouble: Feminism and the Subversion of Identity. London: Routledge.

Chakrabarty, D. (2000) Provincializing Europe: Postcolonial thought and historical difference. Princeton, NJ: Princeton University Press.

Chakrabarty, D. (2009). The climate of history: Four theses. Critical Inquiry 35(2), 197-222.

Chun, C. (2015). Engaging with the everyday: Power and meaning making in an EAP classroom. Bristol: Multilingual Matters.

Cook, G. (2015). 'A pig is a person' or 'You can love a fox and hunt it': Innovation and tradition in the discursive representation of animals. Discourse \& Society 26(5) 587-607.

Cross, J. (2016, February 26). Dusky whaler sharks may have been 'knifed' and killed for a selfie. Daily Telegraph. http://www.dailytelegraph.com.au/newslocal/northern-beaches/duskywhaler-sharks-may-have-been-knifed-and-killed-for-a-selfie/newsstory/e2241cdae5c177dad3815544f964a631 
Dapin, M. (2016, February 6). Shark attack survivors bite back. Sydney Morning Herald. Good Weekend.

http://www.smh.com.au/good-weekend/shark-attack-survivors-bite-back20160202-gmk7jv.html

Evans, V. (2014). The language myth: Why language is not an instinct. Cambridge University Press.

Ferrando, F. (2013). Posthumanism, transhumanism, antihumanism, metahumanism, and new materialisms: Differences and relations. Existenz, 8(2) 26-32.

Fuller, S. (2011). Humanity 2.0: What it means to be human past, present and future. Palgrave-Macmillan.

Gruen, L. \& Weil, K. (2010). Teaching difference: Sex, gender, species. In M. De Mello (Ed.), Teaching the animal (pp. 127-142). Brooklyn: Lantern.

Gruen, L. (1993). Dismantling oppression: an analysis of the connection between women and animals. In G. Gaard (Ed.), Ecofeminism: women, animals, nature (pp. 60-90). Philadelphia: Temple University Press,.

Haraway D. (2008). When Species Meet. Minnesota University Press.

Haraway, D. (2003). The companion species manifesto: Dogs, people and significant otherness. Chicago: Prickly Paradigm Press.

Holborow, M. (2015). Language and neoliberalism. London: Routledge.

Kirksey, S.E. \& Helmreich, S. (2010). The emergence of multispecies ethnography. Cultural Anthropology, 25(4), 545-576. 
Kubota, R. \& A. Lin, A. (2009). Race, culture, and identities in second language education. In R. Kubota and A. Lin (Eds.), Race, culture and identities in second language education: Exploring critically engaged practice (pp. 1-23). New York: Routledge.

Kubota, R. (2014). Race and language learning in multicultural Canada: Toward critical antiracism. Journal of Multilingual and Multicultural Development 36(1), 3-13.

Latour, B. (2004). Politics of nature: How to bring the sciences into democracy. Harvard University Press.

Latour, B. (2015). Telling friends from foes in the time of the Anthropocene. In C. Hamilton, F. Gemenne \& C. Bonneuil (Eds.), The Anthropocene and the global environmental crisis (pp. 145-155). Routledge.

Lorente, B (in press). Scripts of servitude: Language, labor migration and domestic work. Bristol: Multilingual Matters.

Moore, A. (2014). That could be me: Identity and identifcation in discourses about food, meat, and animal welfare. Linguistics and the Human Sciences, 9(1), 59-93.

Motha, S. (2014). Race and empire in English language teaching. New York: Teachers College Press, Columbia University.

Pedersen, H. (2010). Animals in schools: Processes and strategies in human-animal education. Perdue University Press.

Pennycook, A (2016) Posthumanist applied linguistics. Applied Linguistics doi:10.1093/applin/amw016

Pennycook, A (In press) Posthumanist applied linguistics. London: Routledge 
Plumwood, V. (1993). Feminism and the mastery of nature. London and New York: Routledge.

Robson, F. (2015, November 28). Be alert, be afraid: the truth about shark attacks. Sydney Morning Herald. Good Weekend.

http://www.smh.com.au/good-weekend/be-alert-be-afraid-the-truth-aboutshark-attacks-20151124-gl78i6.html

Sabaté I Dilmau, M. (2014). Migrant communication enterprises: Regimentation and resistance. Bristol: Multilingual Matters.

Shipman P. (2011). The animal connection: A new perspective on what makes us human. W. W. Norton \& Company.

Snaza, N. \& Weaver, J.A. (Eds) (2014). Posthumanism and educational research. London and New York: Routledge.

Springgay, S. (2015). 'Approximate-rigorous abstractions': Propositions of activation for posthumanist research in education. In N. Snaza \& J. Weaver (Eds.), Posthumanism and educational research (pp. 76-90). London and New York: Routledge.

Standing, G. (2014) The precariat: The new dangerous class. London: Bloomsbury.

Stibbe, A. (2012). Animals erased: Discourse, ecology and reconnection with the natural world. Middletown: Wesleyan University Press.

Stibbe, A. (2014). Ecolinguistics and erasure: Restoring the natural world to consciousness. In C. Hart \& P. Cap. (Eds.), Contemporary critical discourse studies (pp. 583-602). London and New York: Bloomsbury. 
Stibbe, A. (2015). Ecolinguistics: Language, ecology and the stories we live by. London and New York: Routledge.

Taronga Zoo: Shark attack file (2016)

https://taronga.org.au/animals-conservation/conservation-science/australianshark-attack-file/latest-figures

Thrift, N. (2007). Non-representational theory: Space/ politics/ affect. Routledge.

Thurlow, C. (2016). Queering critical discourse studies or/and Performing 'postclass' ideologies. Critical Discourse Studies, 13:5, 485-514 doi:10.1080/17405904.2015.1122646

Urry J. (2011). Climate change and society. Polity Press.

Wodak, R (2015). The politics of fear: What right-wing populist discourses mean. London: Sage.

Žižek, S. (2010). Living in the end times. Verso. 
Image 1 Wobbegong Shark (photo A Pennycook)

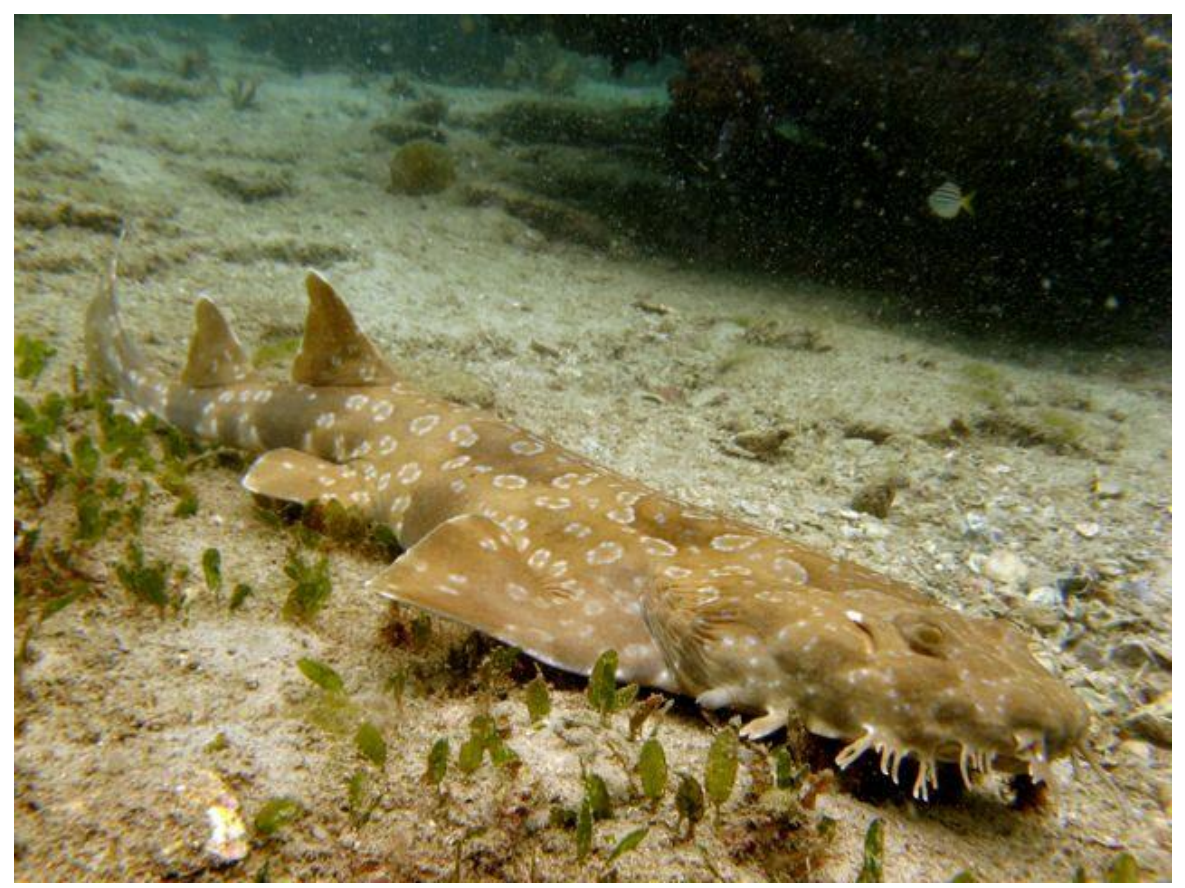

Image 2 Grey Nurse shark (photo A Pennycook)

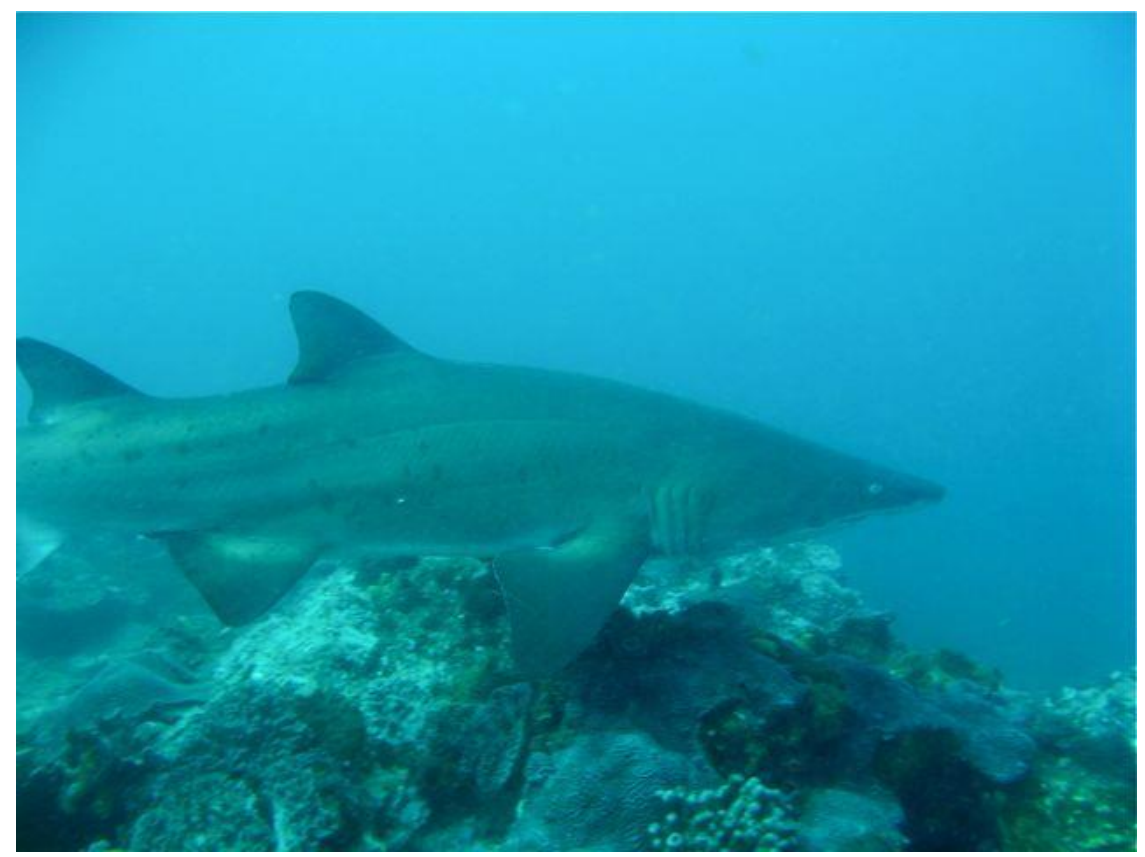




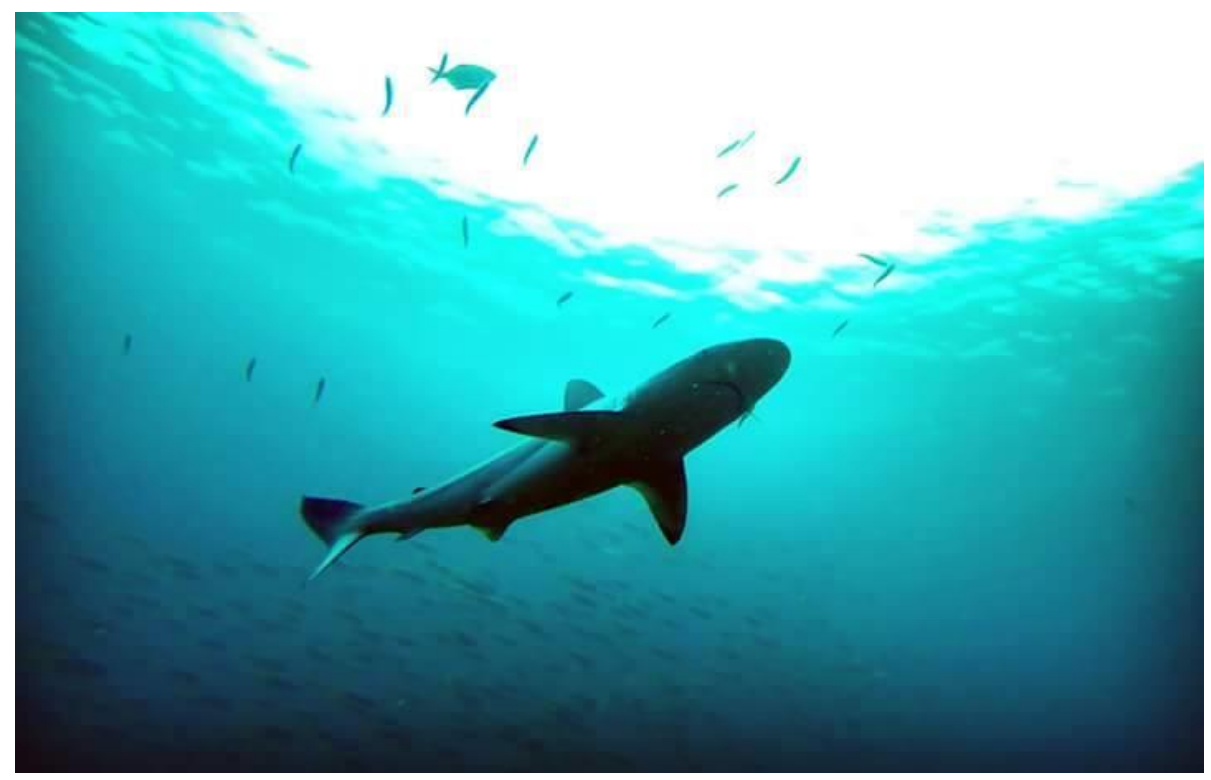

Image 3 Dusky whaler shark at Shelly Beach, Sydney (photo Mauricio Fuentes) 